\title{
Predicting Soil Erosion With RUSLE in Mediterranean Agricultural Systems at Catchment Scale
}

\author{
Manuel López-Vicente and Ana Navas
}

Dept. of Soil and Water, Experimental Station of Aula Dei. Postal Box 13034, 50080 Zaragoza, Spain. Fax: 34976716 145; E-mail: mlopezvicente@gmail.com; anavas@eead.csic.es Corresponding author: Phone: +34 976716 158; E-mail: mlopezvicente@gmail.com

Abstract: Accurate assessment of soil loss is essential for sustainable agricultural production, management and conservation planning, especially in productive rain-fed agro-ecosystems and protected areas. The European Union considers soil as a non-renewable resource and identifies that soil degradation has strong impacts on soil and water resources. In this work the Revised Universal Soil Loss Equation model was applied within a geographic information system in the Estaña catchment (Spanish Pre-Pyrenees) as representative of a Mediterranean agro-ecosystem to elaborate a map of soil erosion at high spatial resolution $(5 \times 5 \mathrm{~m}$ of cell size). The soil erodibility factor $(K)$ is calculated from three different approaches to evaluate the importance of spatial variations in soil texture, field infiltration measurements $\left(K_{f s}\right)$ and amount of coarse fragments. The average value of estimated soil loss for the whole study area is $2.3 \mathrm{Mg} \mathrm{ha}^{-1} \mathrm{yr}^{-1}$ and the highest rates are estimated in crops in steep areas (5.8 $\left.\mathrm{Mg} \mathrm{ha}^{-1} \mathrm{yr}^{-1}\right)$ and trails (18.7 $\mathrm{Mg} \mathrm{ha}^{-1} \mathrm{yr}^{-1}$ ). Cultivated soils with high soil erosion rates (higher than $8 \mathrm{Mg}$ $\mathrm{ha}^{-1} \mathrm{yr}^{-1}$ ) represent $20 \%$ of the cultivated area. The average value of soil loss in areas with human disturbances $\left(4.21 \mathrm{Mg} \mathrm{ha}^{-1} \mathrm{yr}^{-1}\right)$ is 4.4 times higher than that estimated for areas with natural vegetation $\left(0.96 \mathrm{Mg} \mathrm{ha}^{-1} \mathrm{yr}^{-1}\right)$. Field validation with ${ }^{137} \mathrm{Cs}$ shows that the estimated value of soil loss in barley fields with the $K$ - $K_{f s}$-rocks factor improves the model predictions in comparison with those obtained with the $K$-texture and $K$ - $K_{f s}$ factors. The RUSLE model predicts a decrease in soil erosion in fields in accordance with the increase of the age of abandonment. Predicted values of soil erosion and measured soil organic matter and stoniness in old abandoned fields agree with those in areas of natural forest and indicate the recovery of the original conditions of the soil. Statistical analysis highlights that the $C$ factor contributes most of the variability of the values of predicted soil erosion, the $K$ and $L S$ factors contribute in a similar way and the $P$ factor contributes least to the variability of soil erosion. Cultivated soils developed over clay materials in high slope areas are the most susceptible to soil 
degradation processes in comparison with soils developed over limestones in gentle and medium slope areas. The recovery of terraces in steep fields and conservation of crop residues are proposed as soil conservation practices to reduce the magnitude of soil loss in the study area.

Key words: Soil erosion; soil erodibility; RUSLE; ${ }^{137} \mathrm{Cs}$; land uses; Mediterranean agroecosystems

\section{INTRODUCTION}

Soil erosion is one of the main threats in productive croplands (de Paz et al., 2006; LópezBermúdez, 1990) and a limiting factor for the sustainability of semiarid and sub-humid agroecosystems in Spain and other Mediterranean countries that are subject to strong human pressure (Navas et al., 2005). Mediterranean agro-ecosystems are complex landscape units characterized by croplands intersected with patches of natural vegetation, intense land use changes during the last decades including land abandonment, deforestation, overgrazing and extensive agriculture that promote land degradation (Thornes, 2007). Mediterranean soil surface characteristics present high spatial heterogeneity (Corbane et al., 2008) and generally poor conditions (Navas et al., 2007). Values of rainfall erosivity and soil erodibility vary significantly within the year in Mediterranean areas, especially at the end of the summer when extreme storm events happen and in winter due to the freeze-thaw cycles that affect soil structure (López-Vicente et al., 2008). Mediterranean landscapes are erosion-sensitive areas with high and very high rates (> $25 \mathrm{Mg} \mathrm{ha}^{-1} \mathrm{yr}^{-1}$ ) of soil erosion in croplands (Sadiki et al., 2007), irreversible in rills and gullies (> $30 \mathrm{Mg} \mathrm{ha}^{-1} \mathrm{yr}^{-1}$ ) (Desir and Marín, 2007) and low and medium rates in areas with natural vegetation (Zuazo et al., 2004). Hence, the consideration of spatial variations in soil parameters is necessary to improve soil erosion predictions at catchment scale (Nisar Ahamed et al., 2000).

Climate change is increasing both the frequency of heavy rainfall events in Mediterranean areas (e.g. Tapiador et al., 2007) and of extreme daily rainfall in spite of decrease in total amount in Spain and other Mediterranean countries (Alpert et al., 2002). The significant increase in the severity of drought identified from 1951 to 2000 in northeast Spain (VicenteSerrano and Cuadrat-Prats, 2007) had critical consequences in vegetation growing and its protection role on soil surface against water erosion by rainfall splash and runoff. Moreover, desertification enlargement is a serious and a possible imminent scenario in Mediterranean landscapes (Kéfi et al., 2007). 
Soil loss results in substantial on-site and off-site erosion problems that have strong impacts on areas of common interest, such as food safety (loss of fertile soil), water resources, human health, climate change and biodiversity protection. To tackle this problem the United Nations celebrated the Convention to Combat Desertification (IISD, 2007) and the European Union (EU) recently presented the soil protection and amending framework (COM, 2006) and directive (EPC, 2004). Therefore, the accurate assessment of runoff volume and spatially distributed mapping of soil erodibility and erosion is required to understand and quantify the consequences of land use changes, and of interest for local, national and European policy makers to preserve soil and water resources, especially in soil erosion-sensitive areas such as the Mediterranean agricultural systems.

Empirical models are easy to use and low time-consuming and perform equally well as the more complex distributed models (Jetten et al., 2003). Mapping soil erosion with empirical models at continuous temporal scale and GIS techniques allow identifying areas with high erosion rates (Bartsch et al., 2002). The empirical RUSLE model predicts the average annual long-term rates of soil loss at plot and catchment scale (Renard et al., 1991). This model is the most worldwide accepted empirical model and was specially designed for cultivated areas (Renard et al., 1997). The RUSLE model has been used in different environments and under different land uses and spatial scales (e.g. Lewis et al., 2005; Lufafa et al., 2003) and in Mediterranean agro-ecosystems in France (Morschel et al., 2004), Spain (Tejada and Gonzalez, 2006; Boellstorff and Benito, 2005) and Italy (Pelacani et al., 2008; Onori et al., 2006). Calibration of the RUSLE factors to Mediterranean conditions was done in Greece (Arhonditsis et al., 2002) and Palestine (Hammad et al., 2004) and validation of the estimated rates with observed values of soil loss was done in natural conditions and rainfall simulations at plot scale (Spaeth Jr. et al., 2003). However, few works of validation of the RUSLE model has been done in a spatially distributed way in Mediterranean catchments.

This work aims to estimate soil erodibility and erosion rates in the Estaña catchment (Spanish Pre-Pyrenees) as representative of the complex Mediterranean agro-ecosystems. To assess the importance of infiltration properties and coarse fragments on soil erosion the soil erodibility $(K)$ factor is estimated following three different approaches. The accuracy of the different approaches is evaluated with quantified rates of soil loss with ${ }^{137} \mathrm{Cs}$ at several control points in crops of barley. In order to analyze the effect of human disturbances and physiographic properties on soil erosion the annual values of predicted soil erosion are calculated for the different land uses paying special attention in croplands and abandoned fields. This work is of interest to assess the accuracy of three different approaches of soil erodibility as well as to 
103 identify the main land uses causing erosion in the Estaña catchment and to propose soil conservation practices that could be used in other Mediterranean agricultural systems to promote best management practices (BMPs).

\section{MATERIALS AND METHODS}

\section{Study area}

The Estaña catchment is a medium-scale endorheic watershed (246 ha) that is located in the External Ranges of the Central Spanish Pre-Pyrenees and elevation ranges between 676 and $896 \mathrm{~m}$ a.s.l. (Fig. 1). This catchment includes three fresh-water lakes (total area of 17 ha) that are under regional protection since 1997 and are included in the European NATURA 2000 network as Site of Community Importance (SCI). The study area developed on Mesozoic and Neogene materials that are composed by gypsiferous marls, dolimites, limestones, ophites and sparse saline deposits. Karstic processes partially explain the evolution of the landscape of the Estaña catchment with seventeen dolines (López-Vicente et al., 2009). Five of these dolines reach the regional water table and explain the presence of lakes.

This area has a continental Mediterranean climate with two humid periods, one in spring (April and May) and a second in autumn (September and October) and a dry summer with frequent rainfall events of high intensity (López-Vicente et al., 2008). The average value of annual precipitation is 619,536 and $446 \mathrm{~mm}$ at the weather stations of Benabarre, Camporrélls and Canelles, respectively, for the period 1997-2006 (Fig. 1). These weather stations are located north-western, south-western, and south-eastern of the study area at a distance of about $10 \mathrm{~km}$. In spite of the short distance between the weather stations the differences in the annual precipitation are explained by their geographical situation, between the semiarid areas of the Ebro valley to the south and the humid areas of the Pyrenees to the north.

The map of land use and land cover $(L U L C)$ of the study area presents sixteen different land uses (Fig. 1) (López-Vicente, 2008) and shows the aspect of the typical Mediterranean agroecosystem where natural and anthropogenic areas are heterogeneously distributed with frequent changes in land uses from divides to slope-bottom and with a wide range of extension from very small to large size polygons. Crops of winter barley is the main land use (29\% of the total surface) as well as dense (18\%) and open (18\%) Mediterranean forest and dense (10\%) and sparse (5\%) scrublands whereas the other land uses occupies less than 5\% of the total surface and are spread around the study area. However, sparse scrublands are more 
136 frequent in southern-orientated slopes (86\% of total sparse scrublands) and oak forests are more frequent in northern orientated slopes (73\% of total oak forests). Abandoned fields appear in steep slopes where many cropping terraces are tumbledown. Areas with outcrops of massive gypsum have been excluded in the study of soil erosion because the RUSLE model does not simulate erosion processes in rocks. Weather, land uses and tillage practices in the Estaña catchment are representative of rain-fed agricultural areas in Mediterranean mountainous agro-ecosystems.

\section{Estimation of Soil Loss: The RUSLE empirical model}

145 The RUSLE equation (Renard et al., 1997) predicts annual soil loss $\left(A ; \mathrm{Mg} \mathrm{ha}^{-1} \mathrm{yr}^{-1}\right)$ as the 146 product of the factors of rainfall and runoff erosivity $\left(R ; \mathrm{MJ} \mathrm{mm} \mathrm{ha}^{-1} \mathrm{~h}^{-1} \mathrm{yr}^{-1}\right)$, soil erodibility

$147\left(K ; \mathrm{Mg} \mathrm{h} \mathrm{MJ}^{-1} \mathrm{~mm}^{-1}\right)$, slope steep and length $(L S,-)$, cover management $(C,-)$ and support 148 practices $(P,-)$ :

$$
A=R K L S C P
$$

\section{Rainfall and runoff erosivity factor $(R)$}

152 The $R$ factor assesses the effect of the rainfall impact on the soil surface as well as the 153 magnitude of runoff and mathematically is defined as the sum of the storm erosivity index $154\left(E I_{30} ; \mathrm{MJ} \mathrm{mm} \mathrm{ha}{ }^{-1} \mathrm{~h}^{-1}\right)$ of the total number of erosive storm events for the whole year 155 according to the equations:

$$
\begin{aligned}
& R=\frac{1}{n} \sum_{j=1}^{n}\left[\sum_{k=1}^{m}(E)\left(I_{30}\right)_{k}\right] \\
& E I_{30}=(E)\left(I_{30}\right)=\left(\sum_{K=1}^{m} e_{r} \Delta V_{r}\right) I_{30} \\
& e_{r}=0.29\left[1-0.72 \exp \left(-0.05 i_{r}\right)\right]
\end{aligned}
$$

where $E\left(\mathrm{MJ} \mathrm{ha}^{-1}\right)$ is the total storm energy, $I_{30}\left(\mathrm{~mm} \mathrm{~h}^{-1}\right)$ is the maximum intensity in 30 minutes, $j$ is the number of erosive events for the $n$ number of years, $k$ is the temporal interval and $m$ is the number of temporal intervals established for each storm event. The kinetic energy of a storm for each $r$ period, $e_{r}\left(\mathrm{MJ} \mathrm{ha}^{-1} \mathrm{~mm}^{-1}\right)$, is estimated following the approach of Brown and Foster (1987) where $\Delta V_{r}(\mathrm{~mm})$ is the volume of rainfall registered during the $r$ period and $i_{r}\left(\mathrm{~mm} \mathrm{~h}^{-1}\right)$ is the rainfall intensity for the $r$ period. When $n=1$ the calculated $R$ value is the rainfall erosivity for one specific year. 


\section{Soil erodibility factor $(K)$}

Soil erodibility is a complex property and is thought of as the ease with which the soil is detached by splash during rainfall or by runoff or both. The $K$ factor is a lumped parameter that represents an integrated average annual value of the soil profile reaction to the processes of soil detachment and transport by raindrop impact and surface flow, localized deposition due to topography and tillage-induced roughness, and rainwater infiltration into the soil profile (Renard et al., 1997). This factor is assessed as a function of the soil organic content (SOC or $O M, \%)$, the product of the percentages of modified silt $(2-100 \mu \mathrm{m})$ and sand (100$2000 \mu \mathrm{m})(M,-)$, classes of aggregates structure $(s)$ and soil permeability $(p)$ :

$$
K=\frac{\left[2.1 \cdot 10^{-4}(12-O M) M^{1.14}+3.25(s-2)+2.5(p-3)\right]}{100} 0.1317
$$

The RUSLE model established four different soil structure classes and six permeability classes (Table 1). The latest property can be estimated from the different classes of soil texture and from field estimation of the saturated hydraulic conductivity $\left(K_{f s}, \mathrm{~mm} \mathrm{day}^{-1}\right)$.

Surface rock fragments reduce significantly the splash detachment rates in a manner similar to the crop residues that protect the soil surface from raindrop impact. However, in coarse textured soils surface and subsurface rock fragments affect infiltration and thus runoff by reducing the soil void space and soil hydraulic conductivity and increasing the soil erodibility, especially in Mediterranean soils where stone pavements are frequent (Poesen et al., 1998) and significantly modified soil properties (Soto and Navas, 2004). In a previous study, LópezVicente et al. (2006a) observed an increase in the $K$ factor in a set of old abandoned fields in the Estaña catchment due to the high content of coarse fragments in comparison with estimations without accounting the effect of rocks.

Although the percentage of coarse fragments varies along the soil in the same area, rocks appear in the soil profile as a frame, especially in interrill areas, where runoff cannot move them. Moreover, rock fragments larger than $2 \mathrm{~mm}$ were excluded when $K$ values were estimated in Eq. (5). To account the effect of rocks in soil erodibility the RUSLE model includes the following approach:

$$
K_{b} / K_{f s}=\left(1-R_{W}\right)
$$

where $K_{b}\left(\mathrm{~mm} \mathrm{day}^{-1}\right)$ is the modified saturated hydraulic conductivity after accounting the effect of rock fragments, and $R_{W}(\%)$ is the weight percentage of coarse fragments. In this work, the soil erodibility factor is estimated from texture classification (K-texture) and infiltration measurements without $\left(K-K_{f s}\right)$ and with $\left(K-K_{f s}\right.$-rocks $)$ corrections due to soil 
199

200

201

202

203

204

205

206

207

208

209

210

stoniness. Finally, maps of the soil erodibility are equal to zero in urban areas and those with boulder grounds due to the absence of soil.

\section{Topographic factor $(\mathrm{LS})$}

The $L S$ factor describes the combined effect of slope length and steepness and can be considered as a measurement of the sediment transport capacity by runoff. In this work, the $L S$ factor has been calculated following the approach of Moore and Burch (Moore and Wilson, 1992) as a function of the net contributing area $\left(A_{s, i}, \mathrm{~m}\right)$ and the slope angle $\left(\alpha_{i}\right.$, radians). This approach is easy to run within a GIS application and has been satisfactorily used in other Mediterranean areas such as in northeast Spain (Martínez-Casasnovas and Sánchez-Bosch, 2000) and in south Italy (Di Stefano et al., 2000):

$$
L S_{i}=\left(\frac{A_{s, i}}{22.13}\right)^{p}\left(\frac{\sin \alpha_{i}}{0.0896}\right)^{q}
$$

where $p$ and $q$ are two empirical exponents which values were assigned by Moore and Wilson (1992) as $p=0.4$ and $q=1.3$.

\section{Cover management factor $(C)$}

The $C$ factor reflects the effect of cropping and management practices on erosion rates. The soil loss ratio $\left(S L R_{i}\right)$ is an estimate of the ratio of soil loss under actual conditions to losses experienced under reference conditions (clean-tilled continuous-fallow). An individual $S L R_{i}$ value is thus calculated for each time period $i$, as:

$$
S L R_{i}=P L U_{i} C C_{i} S R_{i} S C_{i} S M_{i}
$$

where the sub-factors for each time period $i$ are the prior land $\left(P L U_{i}\right)$, the canopy cover $\left(C C_{i}\right)$, the surface roughness $\left(S R_{i}\right)$, the surface cover $\left(S C_{i}\right)$, and the antecedent soil moisture $\left(S M_{i}\right)$. Each $S L R_{i}$ value is then weighted by the fraction of rainfall and runoff erosivity $\left(E I_{30 i}, \%\right)$ associated with the corresponding time period, and these weighted values are combined into an overall $C$ factor value as:

$$
C=\frac{1}{E I_{30 t}} \sum_{i=1}^{n} E I_{30 i} S L R_{i}
$$

where $E I_{30 t}(\%)$ is sum of $E I_{30 i}$ percentages for the entire time period, $n$ is the total number of time periods $i$. The values of $C$ factor ranges from 0 (total control of the erosion) to 1 (no effectiveness of cover-management practices). The equations for the sub-factors are the following: 


$$
P L U_{i}=C_{f} C_{b} \exp -\left\lfloor\left(c_{u r} B_{u r}\right)+\left(c_{u s} B_{u s} / C_{f}^{C_{u f}}\right)\right\rfloor
$$

$$
C C_{i}=1-F_{c} \exp (-0.1 H)
$$

$$
S R_{i}=\exp \left[-0.66\left(R_{U}-0.24\right)\right]
$$

$$
S C_{i}=\exp \left[-b S_{p}\left(\frac{0.24}{R_{U}}\right)^{0.08}\right]
$$

where $C_{f}$ is a surface-soil-consolidation factor, $C_{b}$ represents the relative effectiveness of subsurface residue in consolidation, $B_{u r}\left(\mathrm{lb}_{\mathrm{acre}}^{-1} \mathrm{in}^{-1}\right)$ is mass density of live and dead roots found in the upper inch of the soil, $B_{u s}$ is mass density of incorporated surface residue in the upper inch of the soil $\left(\mathrm{lb} \mathrm{acre}^{-1} \mathrm{in}^{-1}\right), c_{u f}$ represents the impact of soil consolidation on the effectiveness of incorporated residue and $c_{u r}$ and $c_{u s}$ are calibration coefficients indicating the impacts of subsurface residues. $F_{c}(\%)$ is fraction of land surface covered by canopy, $H(\mathrm{ft})$ is distance that raindrops fall after striking the canopy, $R_{u}$ (in) is surface roughness at initial conditions and just before tillage practices, $b$ is an empirical coefficient that indicates the effectiveness of surface cover in reducing soil erosion and $S_{p}(\%)$ is percentage of land area covered by surface cover. Equations (10), (11), (12) and (13) were empirically formulated by using English units for their inputs. Antecedent soil moisture is an inherent component of continuous-tilled fallow plots, and these effects are reflected in the soil erodibility factor. Hence, no adjustment is made for changes in soil moisture to calculate the $C$ factor.

\section{Support practices factor $(P)$}

249 The $P$ factor is the ratio of soil loss with a specific support practice on croplands to the corresponding loss with upslope and downslope tillage. Support practices in the study area include contouring ( $P_{b}$ sub-factor), stripcropping and buffer strips ( $P_{b}$ sub-factor) and terracing ( $P_{t}$ sub-factor). The $P$ factor is calculated as the product of these sub-factors:

$$
P=P_{b} P_{S} P_{t}
$$

The $P_{b}$ sub-factor measures the effectiveness of orientated furrows and ridges determined by the tillage marks to modify the flow pattern, reducing the detachment and transport capacity by runoff. The $P_{S}$ sub-factor describes how stripcropping and buffer strips, composed by grass and shrub species reduce soil erosion and trap sediments. The $P_{t}$ sub-factor measures the effectiveness of terraces reducing sheet and rill erosion on the terrace interval by breaking the slope into shorter slope lengths. The $P_{t}$ sub-factor is only effective in gentle areas with a slope 
guide of the RUSLE model (Renard et al., 1997) according to the current tillage practices (moldboard plow and cultivator), the map of land uses and after identifying and measuring the length of the terraces in the study area.

\section{Validation with ${ }^{137} \mathrm{Cs}$}

Application of ${ }^{137} \mathrm{Cs}$ technique has provided actual data of average net soil loss and deposition for the last four decades. This technique has been applied in several areas as representative of Mediterranean landscapes, such as in Spain (Navas, 1995; Quine et al., 1994) and Italy (Stefano et al., 2005) and used as an excellent tool to test the accuracy of the spatially distributed predictions of the RUSLE model (Hao et al., 2001). ${ }^{137} \mathrm{Cs}$ is an artificial radionuclide that is strongly fixed to the fine fractions of the soil. Gamma emissions of ${ }^{137} \mathrm{Cs}$ (in $\mathrm{Bq} \mathrm{kg}^{-1}$ air-dry soil) were measured using a high resolution, low background, low energy, coaxial gamma-ray detector of hyperpure germanium coupled to an amplifier and multichannel analyser. Counting time was $30,000 \mathrm{~s}$ and the analytical precision of the measurements was approximately $\pm 10 \%$ (Navas et al., 2005). For this research, erosion rates have been calculated by using fallout ${ }^{137} \mathrm{Cs}$ in eleven soil samples following the approach of Soto and Navas (2004) adapted to Mediterranean soil conditions. The selected soil samples are located in nine different fields of barley as representative of the different physiographic conditions of the study area (Fig. 1).

\section{Database collection}

Rainfall erosivity has been calculated from values of precipitation at the weather station of Canelles for the period 1997-2006 due to the higher temporal resolution of its record (each 15 minutes) in comparison with the weather stations of Camporrélls and Benabarre (daily values). A total of 228 soil samples were collected in a regular net of 100 x $100 \mathrm{~m}$ (Fig. 1). Samples were air-dried, ground, homogenized and quartered, to pass through a $2 \mathrm{~mm}$ sieve and percentages of coarse fragments, clay, silt and sand and soil organic content (SOC) were estimated. The corresponding maps of percentage of coarse fragments, silt, sand and organic matter for the whole study area were obtained by spatial interpolation from data at sampling points. Two types of structure of soil aggregate were identified for the different soil types described at the study area by Machín et al. (2008) and the corresponding map was used to calculate the sub-factor of soil structure. López-Vicente (2008) measured the saturated 
hydraulic conductivity for each soil type obtaining values that range from 9.9 to $2252.5 \mathrm{~mm}$ day $^{-1}$ for Haplic Gypsisols and Haplic Leptosols, respectively.

The parameters of net contributing area and slope steepness of the $L S$ factor have been calculated from the enhanced digital elevation model of the Estaña catchment (López-Vicente et al., 2009) and using a combined flow accumulation algorithm that has proven to better describe the spatial distribution of accumulated surface flow in comparison with simple and multiple flow algorithms (López-Vicente et al., 2006b). In this work, the threshold value of the combined algorithm has been associated to the beginning of the gullies to obtain a more accurate description of the hydrological processes.

The $C$ factor for barley fields was calculated from the $S L R$ values for periods of fifteen days estimated by López-Vicente et al. (2008) for a selected set of fields in the study area whereas an annual constant value of $C$ was calculated for the other land uses from table values included in the guide of the RUSLE model (Renard et al., 1997) and in Table 2. In this work, the parameter of rainfall interception by canopy $(I, 0-1)$ has been added for a better assessment of the canopy cover sub-factor following the approach of Morgan (2001) and values included in Table 2. Rainfall interception is defined as the amount of rainfall that remains in the branches and leaves of the canopy and crop residues and returns to the atmosphere by evaporation.

\section{RESULTS AND DISCUSSION}

Values of rainfall erosivity and maximum intensity range between 2 and $1216.3 \mathrm{MJ} \mathrm{mm} \mathrm{ha}^{-1}$ $\mathrm{h}^{-1}$ and between 1.6 and $69.8 \mathrm{~mm} \mathrm{~h}^{-1}$, respectively, with mean values of $81.3 \mathrm{MJ} \mathrm{mm} \mathrm{ha} \mathrm{h} \mathrm{h}^{-1}$ and $15.2 \mathrm{~mm} \mathrm{~h}^{-1}$. The mean value of the $R$ factor is $1000.3 \mathrm{MJ} \mathrm{mm} \mathrm{ha}^{-1} \mathrm{~h}^{-1} \mathrm{yr}^{-1}$, with a minimum of $215 \mathrm{MJ} \mathrm{mm} \mathrm{ha}{ }^{-1} \mathrm{~h}^{-1} \mathrm{yr}^{-1}$ in 2004 and a maximum of 1969.2 $\mathrm{MJ} \mathrm{mm} \mathrm{ha}^{-1} \mathrm{~h}^{-1} \mathrm{yr}^{-1}$ in 1998. The three estimated maps of soil erodibility present similar mean values that range between 0.009 and $0.011 \mathrm{Mg} \mathrm{h} \mathrm{MJ}^{-1} \mathrm{~mm}^{-1}$ for $K-K_{f s}$ and $K$-texture, respectively, though maximum values and areas with low values vary significantly between $K$-texture and the other two approaches (Fig. 2). The maximum value of soil erodibility is equal for $K-K_{f s}$ and $K-K_{f s}$-rocks and is $39 \%$ higher than that obtained with $K$-texture. In the three maps those areas associated to soil samples with loam and sandy loam textures and blocky and massive structure present high values of soil erodibility whereas soils with silty clay loam texture and medium or coarse granular structure present low values. Soil erodibility maps calculated from infiltration values present a higher spatial variability and complexity that is related to the different soil types. Coarse fragments reduce the saturated hydraulic conductivity in a 
percentage of $30.7 \%$ that is similar to the mean percentage of coarse fragments in the soil profile for the study area. However, the effect of these changes in the values of the class permeability sub-factor of the Eq. (5) is limited to those areas with high values of coarse fragments obtaining a mean value of $K$ - $K_{f s}$-rocks that is only $6.1 \%$ higher than the value calculated for $K-K_{f s}$. Maps of $K-K_{f s}$ and $K-K_{f s}$-rocks present a value of zero in areas with high values of soil organic content (SOC), saturated hydraulic conductivity and percentage of coarse fragments.

The map of the $L S$ factor has a mean value of 5.1 and a maximum of 61.3 (Fig. 2.d). Steep areas and those located in gullies present high values of the $L S$ factor, whereas flat areas ( $\alpha_{i}=0$ ) that represent a percentage of $0.14 \%$ of the study area, have a value of zero. The $L S$ factor presents low values at headwater due to the key role of the map of flow accumulation in these areas, whereas in the rest of the flow-path the $L S$ factor is more sensitive to the parameter of slope steepness. The map of the $C$ factor has a mean value of 0.072 and is very sensitive to the different land uses (Fig. 2.e). The highest values (low soil protection) are associated to paths and crops and the lowest (high soil protection) to dense scrublands, poplars, pine woodlands and pastures.

The map of $P$ factor has a mean value of 0.76 and minimum of 0.6 in barley fields and 1.0 in the rest of the study area (Fig. 2.f). Stripcropping is the most effective support practice and explain the lowest values of the $P$ factor in the steep small fields of the study area. Contouring effectiveness is sensitive to slope steepness being non-effective in a percentage of $2.4 \%$ of the area of the fields and explains the values of the $P$ factor of the fields that surround the lakes. From a total of 32 terraced fields in the study area (4.2 ha) the $P_{t}$ sub-factor only reduces the predicted rates of soil loss in three pixels $\left(75 \mathrm{~m}^{2}\right)$ with values of $0.55,0.69$ and 0.8 and a mean value for the total surface of barley fields of 0.9994 .

Potential annual soil loss $\left(A_{p}, \mathrm{Mg} \mathrm{ha}^{-1} \mathrm{yr}^{-1}\right)$ is estimated from the product of the $R, K$ and $L S$ factors and represents the scenario of a total lack of vegetation and support practices. Potential and actual maps of soil loss are calculated with the more complex approach of the $K-K_{f s}$-rocks factor. The mean value of $A_{p}$ for the Estaña catchment is $54.1 \mathrm{Mg} \mathrm{ha}^{-1} \mathrm{yr}^{-1}$ being lower than the mean value of $95.1 \mathrm{Mg} \mathrm{ha}^{-1} \mathrm{yr}^{-1}$ calculated by Onori et al. (2006) in the Comunelli catchment (Sicily, Italy) with the RUSLE model and similar to that of $55.4 \mathrm{Mg} \mathrm{ha}^{-1} \mathrm{yr}^{-1}$ estimated by Sadiki et al. (2004) in the Rif mountains of Morocco with the USLE model. The average soil erosion rate estimated with the RUSLE model for the study area is $2.3 \mathrm{Mg} \mathrm{ha}^{-1}$ 
$\mathrm{yr}^{-1}$ (Fig. 3). This lower rate by comparing with the potential erosion highlights the key role of vegetation cover and conservation practices in reducing soil erosion rates.

Tolerable soil loss $\left(T ; \mathrm{Mg} \mathrm{ha}^{-1} \mathrm{yr}^{-1}\right)$ is defined as the maximum rate of soil erosion that can occur and still permit crop productivity to be sustained economically after considering rates of soil formation. Values of $T$ range from 2.2 to $11.2 \mathrm{Mg} \mathrm{ha}^{-1} \mathrm{yr}^{-1}$ according to the RUSLE model for soils in the USA. In Spain, De la Horra (1992) calculated a mean value of $T$ of 6 $\mathrm{Mg} \mathrm{ha}^{-1} \mathrm{yr}^{-1}$ at the province of Toledo (Central Spain) that was used by Boellstorff and Benito (2005) to compare the estimated rates of soil erosion with RUSLE in the same area and used in this work to evaluate the predicted rates of soil loss. A maximum of $40 \mathrm{Mg} \mathrm{ha}^{-1} \mathrm{yr}^{-1}$ is considered as the limit between very high and irreversible stages of soil loss. The histogram of the map of predicted soil loss shows that $88 \%$ of the soil surface at the Estaña catchment has low and medium rates of erosion and only $1.8 \%$ of the surface high, very high and irreversible rates (Fig. 3). Flat areas and those which $K$ factor value is zero present no erosion and only represent $0.4 \%$ of the total study area.

Validation with ${ }^{137} \mathrm{Cs}$ of estimated soil erosion in barley fields with RUSLE with the three different approaches for estimating the $K$ factor shows that estimation of soil losses with the $K-K_{f s}$-rocks factor lightly improves the model predictions in comparison with the predictions obtained with the $K$-texture and $K$ - $K_{f s}$ factors (Table 3). The estimated rates of soil erosion with the three different approaches are lower than the measured rate with ${ }^{137} \mathrm{Cs}$. This situation can be explained by the low values of precipitation recorded at the Canelles weather station during the period 1997-2006 (mean annual precipitation of $446 \mathrm{~mm}$ ) in comparison with the mean annual precipitation during the last four decades (mean annual precipitation during the reference period of 1961-1990 of 520 mm). Furthermore, it is necessary to consider that predicted values are modelled for a raster cell area of 5 x 5 meters whereas control points are representative of punctual measurements.

Trails present the highest average value of soil loss $\left(19 \mathrm{Mg} \mathrm{ha}^{-1} \mathrm{yr}^{-1}\right)$ that is explained by the high value of the $C$ factor (Table 4). Total erosion for this land use represents $14 \%$ of the total erosion predicted for the Estaña catchment though its total surface is only $2 \%$ of the total area. Therefore, paths and trails are small-scale anthropogenic disturbances that strongly contribute to soil degradation. These results agree with those obtained by several authors in other areas in the world (e.g. Ricker et al., 2008; Rijsdijk et al., 2007).

The mean value of erosion for barley fields in steep areas is $5.8 \mathrm{Mg} \mathrm{ha}^{-1} \mathrm{yr}^{-1}$ that is almost equal to the tolerable value of erosion proposed by De la Horra (1992). Total soil loss in these fields represents $44 \%$ of total erosion in the Estaña catchment and only $18 \%$ of the surface of 
the study area. Furthermore, the average value of soil loss in steep fields is $56 \%$ higher than the average rate estimated for fields in gentle areas. These land uses with tolerable and very high rates of erosion also have areas with very low rates, even no erosion.

Open Mediterranean forest, barley fields in gentle areas and disperse scrubland present low average values $\left(1-4 \mathrm{Mg} \mathrm{ha}^{-1} \mathrm{yr}^{-1}\right)$ of soil erosion whereas the rest of land uses has very low rates of soil loss (less than $1 \mathrm{Mg} \mathrm{ha}^{-1} \mathrm{yr}^{-1}$ ) (Table 4). The average soil erosion rate for the areas with anthropogenic land uses $\left(4.21 \mathrm{Mg} \mathrm{ha}^{-1} \mathrm{yr}^{-1}\right)$ is 4.4 times higher than that estimated for the areas with natural vegetation $\left(0.96 \mathrm{Mg} \mathrm{ha}^{-1} \mathrm{yr}^{-1}\right)$. These results agree with those calculated by Sadiki et al. (2007) with ${ }^{137} \mathrm{Cs}$ in Morocco where cereal crops have average values of soil loss much higher than those on scrubland and fallow land.

Within the areas of natural vegetation, the average value of soil erosion in scrublands is lower than the average value in Mediterranean forest. These results agree with those obtained by Casermeiro et al. (2004) in Central Spain and by Navas and Walling (1992) in north-eastern Spain and highlight the more effective role of shrubs to avoid soil erosion and promote sediment accumulation. In areas of anthropogenic land uses there is a decrease in the estimated value of soil loss in relation to the age of abandonment of fields (Table 4) and an increase in the percentage of soil organic content (SOC) from 2.7 to $3.9 \%$ and of coarse fragments from 23 to $36 \%$. These results are associated to complex processes of natural vegetation re-growth and exportation of fine particles of the soil profile, especially in top soil layers. Values of soil loss, SOC and percentage of coarse fragments in old abandoned fields are almost equal to those obtained in dense Mediterranean forest. Hence, soil quality in old abandoned fields has achieved the standards of natural soils in the Estaña catchment. These results disagree with those calculated by Navas et al. (1997) in Central Pyrenees where abandoned fields have higher values of soil loss than those in fields in use and highlight the complexity and spatial heterogeneity of the processes of soil erosion and recovery in Mediterranean abandoned farmlands.

Cultivated soils present higher rates of soil erosion than those soils in scrublands and oak and Mediterranean forest for the different parent materials and slope steepness conditions in the study area (Fig. 4). Cultivated soils developed over clay materials in high slope areas present the highest soil erosion rates and are the most susceptible to suffer intense soil erosion (higher than $8 \mathrm{Mg} \mathrm{ha}^{-1} \mathrm{yr}^{-1}$ ). Soils developed over limestones in forested areas with low and medium slope present the lowest values of soil erosion (less than $1 \mathrm{Mg} \mathrm{ha}^{-1} \mathrm{yr}^{-1}$ ).

Statistical analysis of each factor at sampling points shows that the cover-management factor (C) contributes most of the variability of the values of predicted soil erosion, the $K$ and $L S$ 
factors contribute a similar amount and the $P$ factor contributes least to the variability of $A$. The $R$ factor is not considered in the analysis because of its constant value for the study area. The high number of inputs to calculate the $C$ factor and of land uses in Mediterranean landscapes suggests the necessity of field measurements of these parameters, especially in areas with natural vegetation where the $C$ factor has very low values. On the other hand, the addition of an antecedent soil moisture sub-factor to the soil erodibility factor may improve its quality predictions due to the seasonal variability of this soil property in Mediterranean environments (López-Vicente et al., 2008) and its importance in soil saturation and runoff processes (Terzoudi et al., 2007). To promote sustainable strategies we propose to delay the plowing practices just before seeding to extend the protection role by the crop residues accounted in the $C$ factor. We also propose to recover tumbledown cropping terraces that appear in the steep slopes of the study area to increase the effect of the $P$ factor to reduce the magnitude of overland flow and to increase the trap efficiency of soil eroded particles by vegetation. These practices can be applied in other Mediterranean agro-ecosystems to avoid soil erosion and thus to promote sustainable agricultural practices.

\section{CONCLUSIONS}

The application of the RUSLE model with a high resolution database of its input values allows detailed mapping of spatially distributed soil erosion rates at the Estaña catchment. The more complex approach of the $K$ soil erodibility factor calculated from field infiltration measurements and accounting the effect of coarse fragments improves estimations of soil erosion rates in barley fields and fits best with the quantified values of soil loss with ${ }^{137} \mathrm{Cs}$. Hence, the consideration of these soil properties is of interest for a better application of the RUSLE model in Mediterranean environments where stone pavements are frequents and modify the saturated hydraulic conductivity of the soil.

Although soil erosion does not appear to be a problem for most of the study area high and very high values of soil loss are estimated for crops in steep areas and developed over clay materials. The average value of soil loss in areas with human disturbances (cultivated and abandoned fields and paths) is more than four times higher than that estimated for areas with natural vegetation. The RUSLE model predicts a decrease in the values of soil erosion in fields in accordance with the increase of the age of abandonment. Predicted values of soil erosion and measured of soil organic content (SOC) and stoniness in old abandoned fields are comparable with those in areas of natural forest and suggest a recovery of the original soil conditions. 
461

462

463

464

465

466

467

468

469

470

471

472

473

474

475

476

477

478

479

480

481

482

483

484

485

486

487

488

489

490

491

492

493

494

The $C$ factor explains most of the variability of the predicted values of soil erosion and its more detailed estimation may be done in forthcoming research to improve quality predictions of soil loss. Conservation policies should be established in areas with clay materials in steep cultivated and not cultivated slopes to avoid an irreversible state of soil degradation. The delay of plowing practices and the recovery of tumbledown cropping terraces are suggested as sustainable agricultural practices to reduce soil erosion in Mediterranean agro-ecosystems.

\section{ACKNOWLEDGEMENTS}

This research was financially supported by the following project: "Soil erosion and carbon dynamic in Mediterranean agroecosystems: radioisotopic modelling at different spatial and temporal scales" (MEDEROCAR, CGL2008-00831/BTE) funded by the Spanish Ministry of Science and Innovation.

\section{REFERENCES}

Alpert, P., Ben-Gai, T., Baharad, A., Benjamín, Y., Yekutieli, D., Colación, M., Diodato, L., Ramis, C., Homar, V., Romero, R., Michaelides, S., and A. Manes. 2002. The paradoxical increase of Mediterranean extreme daily rainfall in spite of decrease in total values. Geophys. Res. Lett. 29(11): 1536.

Arhonditsis, G., Giourga, C., Loumou, A., and M. Koulouri. 2002. Quantitative assessment of agricultural runoff and soil erosion using mathematical modeling: Applications in the Mediterranean region. Environ. Manage. 30: 434-453.

Ashby, M. 1999. Modelling the water and energy balances of Amazonian rainforest and pasture using Anglo-Brazilian Amazonian climate observation study area. Agr. Forest Meteorol. 94: 79-101.

Bartsch, K.P., Van Miegroet, H., Boettinger, J., and J. P. Dobrowolski. 2002. Using empirical erosion models and GIS to determine erosion risk at Camp Williams, Utah. J. Soil Water Conserv. 57(1): 29-37.

Belmonte, F., and A. Romero. 1998. La cubierta vegetal en las regiones áridas y semiáridas: consecuencias de la interceptación de la lluvia en la protección del suelo y los recursos hídricos / Canopy cover in arid and semi-arid regions: consequences of rainfall interception on soil protection and water resources. NORBA-Journal of Geography 10: 9-22.

Boellstorff, D., and G. Benito. 2005. Impacts of set-aside policy on the risk of soil erosion in central Spain. Agr. Ecosyst. Environ. 107: 231-243.

Brown, L.C., and G. R. Foster. 1987. Storm erosivity using idealized intensity distributions, T. ASAE 30: 379-386. 
Carreiras, J.M.B., Pereira, J.M.C., and J. S. Pereira. 2006. Estimation of tree canopy cover in evergreen oak woodlands using remote sensing. Forest Ecol. Manag. 223: 45-53.

Casermeiro, M.A., Molina, J.A., de la Cruz Caravaca, M.T., Hernando Costa, J., Hernando Massanet, M.I., and P. S. Moreno. 2004. Influence of scrubs on runoff and sediment loss in soils of Mediterranean climate. Catena 57: 91-107.

COM (Commission of the European Communities). 2006. Proposal for a Directive of the European Parliament and of the Council establishing a framework for the protection of soil and amending Directive 2004/35/EC (presented by the Commission). COM(2006) 232 final. 2006/0086 (COD). Brussels, Belgium.

Corbane, C., Andrieux, P., Voltz, M., Chadœuf, J., Albergel, J., Robbez-Masson, J.M., and P. Zante. 2008. Assessing the variability of soil surface characteristics in row-cropped fields: The case of Mediterranean vineyards in Southern France. Catena 72(1): 79-90.

De la Horra, J.L. 1992. Aspectos biogeográficos en relación con la problemática agraria de la comarca de Torrijos (Toledo) / Biogeographic aspects in relation with the problemmatic agricultura in Torrijos. Ph.D. Thesis, Universidad Complutense de Madrid, Spain.

de Paz, J.-M., Sánchez, J., and F. Visconti. 2006. Combined use of GIS and environmental indicators for assessment of chemical, physical and biological soil degradation in a Spanish Mediterranean region. J. Environ. Manage. 79(2): 150-162.

Desir, G., and C. Marín. 2007. Factors controlling the erosion rates in a semi-arid zone (Bardenas Reales, NE Spain). Catena 71(1): 31-40.

Di Stefano, C., Ferro, V., and P. Porto. 2000. Length Slope Factors for applying the Revised Universal Soil Loss Equation at Basin Scale in Southern Italy. J. Agr. Eng. Res. 75: 349-364.

Eberbach, P., and M. Pala. 2005. Crop row spacing and its influence on the partitioning of evapotranspiration by winter-grown wheat in Northern Syria. Plant Soil 268: 195-208.

EPC (European Parliament and of the Council). 2004. Directive 2004/35/CE of the European Parliament and of the Council of 21 April 2004 on environmental liability with regard to the prevention and remedying of environmental damage. Official Journal of the European Union L $143 / 56$.

Hammad, A.A., Lundekvam, H., and T. Børresen. 2004. Adaptation of RUSLE in the Eastern Part of the Mediterranean Region. Environ. Manage. 34(6): 829-841.

Hao, Y., Lal, R., Izaurralde, R.C., Ritchie J.C., Owens, L.B., and D. L. Hothem. 2001. Historic assessment of agricultural impacts on soil and soil organic carbon erosion in an Ohio watershed. Soil Sci. 166(2): 116-126.

IISD. 2007. Summary of the first extraordinary session of the conference of the parties to the UNCCD: 26 november 2007. Earth Negotiations Bulletin 4(207): 1-2.

IPE-GA. 2005. Atlas de la Flora de Aragón/Atlas of the vegetation of Aragon. Available from: http://www.ipe.csic.es/floragon/. (C Copyright 2005 
Jetten, V., Govers, G., and R. Hessel. 2003. Erosion models: Quality of spatial predictions. Hidrol. Process. 17(5): 887-900.

Kéfi, S., Rietkerk, M., Alados, C.L., Pueyo, Y., Papanastasis, V.P., ElAich, A., and P. C. de Ruiter. 2007. Spatial vegetation patterns and imminent desertification in Mediterranean arid ecosystems. Nature 449(7159): 213-217.

Lewis, L.A., Verstraeten, G., and H. L. Zhu. 2005. RUSLE applied in a GIS framework: Calculating the LS factor and deriving homogeneous patches for estimating soil loss. Int. J. Geogr. Inf. Sci. 19(7): 809-829.

Llorens, P., and F. Domingo. 2007. Rainfall partitioning by vegetation under Mediterranean conditions. A review of studies in Europe. J. Hydrol. 335: 37-54.

López-Bermúdez, F. 1990. Soil erosion by water on the desertification of a semi-arid Mediterranean fluvial basin: the Segura basin, Spain. Agr. Ecosyst. Environ. 33(2): 129-145.

López-Vicente, M. 2008. Erosión y redistribución del suelo en agroecosistemas mediterráneos: Modelización predictiva mediante SIG y validación con ${ }^{137}$ Cs (Cuenca de Estaña, Pirineo Central) / Soil erosion and redistribution in Mediterranean agro-ecosystems: predictive modelling with GIS and validation with ${ }^{137} \mathrm{Cs}$ (Estaña catchment, Spanish Central Pyrenees). University of Zaragoza, Spain.

López-Vicente, M., A. Navas, and J. Machín. 2006a. Variation of soil erodibility in abandoned fields: A case study in the Carrodilla Range (Spanish Pyrenees). In Soil and Water Conservation Under Changing Land Use. Martínez-Casasnovas J.A., I. Pla Sentís, M.C. Ramos Martín, J.C. Balasch Solanes (eds.). Universitat de Lleida. Lérida, Spain. pp. 167-170.

López-Vicente, M., Navas, A., and J. Machín. 2008. Identifying erosive periods by using RUSLE factors in mountain fields of the Central Spanish Pyrenees. Hydrol. Earth Syst. Sc. 12(2): 1-13.

López-Vicente, M., A. Navas, and J. Machín. 2009. Geomorphic mapping in endorheic subcatchments in the Spanish Pyrenees: An integrated GIS analysis of topographic-karstic features. Geomorphology DOI: 10.1016/j.geomorph.2008.03.014.

López-Vicente, M., Navas, A., Machín, J., and L. Gaspar. 2006b. Modelización de la pérdida de suelo en una cuenca endorreica del Pirineo oscense / Modelling soil loss in an endorheic catchment of the Spanish Pyrenees. Cuadernos de Investigación Geográfica 32: 29-42.

Lufafa, A., Tenywa, M.M., Isabirye, M., Majaliwa, M.J.G., and P. L. Woomer. 2003. Prediction of soil erosion in a Lake Victoria basin catchment using a GIS-based Universal Soil Loss model. Agr. Syst. 76(3): 883-894.

Machín, J., López-Vicente, M., and A. Navas. 2008. Cartografía digital de suelos de la Cuenca de Estaña (Prepirineo Central) / Digital mapping of soils of the Estaña catchment (Central PrePyrenees). In: Benavente, J., and F. J. Gracia (Eds.): Trabajos de Geomorfología en España, 20062008. SEG. Cádiz, Spain, pp. 477-480. 
Martínez-Casasnovas, J.A., and I. Sánchez-Bosch. 2000. Impact assessment of changes in land use/conservation practices on soil erosion in the Penedès-Anoia vineyard region (NE Spain). Soil Till. Res. 57: 101-106.

Moore, I.D., and J. P. Wilson. 1992. Length-slope factors for the Revised Universal Soil Loss Equation: simplified method of estimation. J. Soil Water Conserv. 47(5): 423-428.

Morschel, J., Fox, D.M., and J.-F. Bruno. 2004. Limiting sediment deposition on roadways: topographic controls on vulnerable roads and cost analysis of planting grass buffer strips. Environ. Sci. Policy 7: 39-45.

Morgan, R.P.C. 2001. A simple approach to soil loss prediction: a revised Morgan-Morgan-Finney model. Catena 44: 305-322.

Nagler, P.L., Glenn, E.P., Thompsona, T.L., and A. Huete. 2004. Leaf area index and normalized difference vegetation index as predictors of canopy characteristics and light interception by riparian species on the Lower Colorado River. Agr. Forest Meteorol. 125: 1-17.

Navas, A. 1995. Cuantificación de la erosión mediante el radioisótopo cesio 137. Sociedad Española de Geomorfología / Assessment of erosion with the radioisotop Caesium 137. Cuadernos Técnicos de la SEG, 8.

Navas, A., García-Ruiz, J.M., Machín, J., Lasanta, T., Walling, D., Quine, T., and B. Valero. 1997. Aspects of soil erosion in dry farming land in two changing environments of the central Ebro valley, Spain. IAHS Publi. 245: 13-20.

Navas, A., Machín, J., and J. Soto. 2005. Assessing soil erosion in a Pyrenean mountain catchment using GIS and fallout ${ }^{137}$ Cs. Agr. Ecosyst. Environ. 105(3): 493-506.

Navas, A., and D. Walling. 1992. Using caesium-137 to assess sediment movement in a semiarid upland environment in Spain. IAHS 209: 129-138.

Navas, A., Walling, D.E., Quine, T., Machín, J., Soto, J., Domenech, S., and M. López-Vicente. 2007. Variability in ${ }^{137} \mathrm{Cs}$ inventories and potential climatic and lithological controls in the central Ebro valley, Spain. J. Radioanal. Nucl. Ch. 274(2): 331-339.

Nisar Ahamed, T.R., Gopal Rao, K., and J. S. R. Murthy. 2000. Fuzzy class membership approach to soil erosion modelling. Agr. Syst. 63(2): 97-110.

Onori, F., De Bonis, P., and S. Grauso. 2006. Soil erosion prediction at the basin scale using the revised universal soil loss equation (RUSLE) in a catchment of Sicily (southern Italy). Environ. Geol. 50: 1129-1140.

Pelacani, S., Märker, M., and G. Rodolfi. 2008. Simulation of soil erosion and deposition in a changing land use: A modelling approach to implement the support practice factor. Geomorphology 99(1-4): 329-340.

Poesen, J.W., van Wesemael, B., Bunte, K., and A. Solé-Benet. 1998. Variation of rock fragment cover and size along semiarid hillslopes: a case-study from southeast Spain. Geomorphology 23: $323-335$. 
Quine, T., Navas, A. Walling, D.E., and J. Machín. 1994. Soil erosion and redistribution on cultivated and uncultivated land near Las Bardenas in the Central Ebro River Basin, Spain. Land Degrad. Rehabil. 5: 41-55.

Rambal, S., Ourcival, J.M., Offre, R.J., Mouillot, F., Nouvellon, Y., Reichstein, M., and A. Rocheteau. 2003. Drought controls over conductance and assimilation of a Mediterranean evergreen ecosystem: scaling from leaf to canopy. Global Change Biol. 9: 1813-1824.

Renard, K.G., Foster, G.R., Weesies, G.A., McCool, D.K., and D. C. Yoder. 1997. Predicting Soil Erosion by Water: A Guide to Conservation Planning with the Revised Universal Soil Loss Equation (RUSLE). Handbook \#703. US Department of Agriculture, Washington, DC.

Renard, K.G., Foster, G.R., Weesies, G.A., and J. P. Porter. 1991. RUSLE - Revised universal soil loss equation. J. Soil Water Conserv. 46(1): 30-33.

Ricker, M.C., Odhiambo, B.K., and J. M. Church. 2008. Spatial analysis of soil erosion and sediment fluxes: A paired watershed study of two Tappahannock River tributaries, Stafford County, Virginia. Environ. Manage. 41(5): 766-778.

Rijsdijk, A., Sampurno Bruijnzeel, L.A., and C. Kukuh Sutoto. 2007. Runoff and sediment yield from rural roads, trails and settlements in the upper Konto catchment, East Java, Indonesia. Geomorphology 87: 28-37.

Rodríguez, A.B.M., and S. Schnabel. 1998. Medición de la interceptación de las precipitaciones por la encina (Quercus rotundifolia lam.): metodología e instrumentalización / Measurement of rainfall interception by oak trees (Quercus rotundifolia lam.): methodology and instrumentation. NORBAJournal of Geography 10: 95-112.

Rodríguez-Calcerrada, J., Pardos, J.A., Gil, L., and I. Aranda. 2007. Summer field performance of Quercus petraea (Matt.) Liebl and Quercus pyrenaica Willd seedlings, planted in three sites with contrasting canopy cover. New Forest. 33: 67-80.

Sadiki, A., Bouhlassa, S., Auajjar, J., Faleh, A., and J. J. Macaire. 2004. Utilisation d'un SIG pour l'évaluation et la cartographie des risques d'érosion par l'Equation universelle des pertes en sol dans le Rif oriental (Maroc): cas du bassin versant de l'oued Boussouab. Bulletin de l'Institut Scientifique, Rabat, section Sciences de la Terre 26: 69-79.

Sadiki, A., Faleh, A., Navas, A., and S. Bouhlassa. 2007. Assessing soil erosion and control factors by the radiometric technique in the Boussouab catchment, Eastern Rif, Morocco. Catena 71(1): 13-20.

Soto, J., and A. Navas. 2004. A model of ${ }^{137}$ Cs activity profile for soil erosion studies in uncultivated soils of Mediterranean environments. J. Arid Environ. 59: 719-730.

Spaeth Jr., K.E., Pierson Jr., F.B., Weltz, M.A., and W. H. Blackburn. 2003. Evaluation of USLE and RUSLE estimated soil loss on rangeland. J. Range Manage. 56(3): 234-246.

Staelens, J., De Schrijver, A., Verheyen, K., and N. E. C. Verhoest. 2006. Spatial variability and temporal stability of throughfall water under a dominant beech (Fagus sylvatica L.) tree in relationship to canopy cover. J. Hydrol. 330: 651- 662. 
642 Stefano, C.D., Ferro, V., Porto, P., and S. Rizzo. 2005. Testing a spatially distributed sediment 643 delivery model (SEDD) in a forested basin by cesium-137 technique. J. Soil Water Conserv. 60(3): $644 \quad 148-157$.

645 Tapiador, F.J., Sanchez, E., and M. A. Gaertner. 2007. Regional changes in precipitation in Europe 646 under an increased greenhouse emissions scenario. Geophys. Res. Lett. 34(6): L06701.

647 Tejada, M., and J. L. Gonzalez. 2006. The relationships between erodibility and erosion in a soil 648 treated with two organic amendments. Soil Till. Res. 91: 186-198.

649 Terzoudi, C.B., Gemtos, T.A., Danalatos, N.G., and I. Argyrokastritis. 2007. Applicability of an 650 empirical runoff estimation method in central Greece. Soil Till. Res. 92: 198-212.

651 Thornes, J.B. 2007. Modelling Soil Erosion by Grazing: Recent Developments and New Approaches. 652 Geogr. Res. 45(1): 13-26.

653 Vicente-Serrano, S.M., and J. M. Cuadrat-Prats. 2007. Trends in drought intensity and variability in 654 the middle Ebro valley (NE of the Iberian peninsula) during the second half of the twentieth 655 century. Theor. Appl. Climatol. 88(3-4): 247-258.

656 Zuazo, V.H.D., Martínez, J.R.F., and A. M. Raya. 2004. Impact of vegetative cover on runoff and soil 657 erosion at hillslope scale in Lanjaron, Spain. Environmentalist 24(1): 39-48.

658

659 
660 TABLE 1. Classes of soil permeability and structure according to the different types of texture, infiltration 661 properties and type of aggregates.

\begin{tabular}{llr}
\hline Permeability class & \multicolumn{1}{c}{ Texture } & \multicolumn{2}{c}{ Saturated hydraulic conductivity } \\
\cline { 3 - 3 } & & \multicolumn{2}{c}{$\left(\mathrm{mm} \mathrm{h}^{-1}\right)$} \\
\hline 1 & Sand & $20.3-61.0$ \\
2 & Loamy sand, sandy loam & $5.1-20.3$ \\
3 & Loam, silt loam & $2.0-5.1$ \\
4 & Sandy clay loam, clay loam & $1.0-2.0$ \\
5 & Silty clay loam, sand clay & \\
6 & Silty clay, clay & \\
\hline Structure class & & \\
\hline 1 & & Type of soil aggregate structure \\
2 & Very fine granular $(<1 \mathrm{~mm})$ & \\
3 & Fine granular $(1-2 \mathrm{~mm})$ & \\
4 & Medium or coarse granular $(2-10 \mathrm{~mm})$ & \\
\hline
\end{tabular}

662 
663 TABLE 2. Summary of values for calculating the cover management factor for the different land-uses.

\begin{tabular}{|c|c|c|c|c|}
\hline \multicolumn{2}{|c|}{ Land-use and land-cover type } & $\mathrm{PH}(\mathrm{m})$ & \multirow{2}{*}{$\begin{array}{r}\mathrm{CC}(\%) \\
0\end{array}$} & RI $(\%)$ \\
\hline Anthropogenic & Path & 0 & & 0 \\
\hline \multirow[t]{5}{*}{ Use } & Winter barley & $0-0.46^{(1)} ; 0.10^{*}$ & $30.42^{(1)}$ & $0-3^{* *(2)}-14^{(3)} ; 7.33^{*}$ \\
\hline & Pasture & $0.28^{(2)}$ & $100^{(1)}$ & $8.33^{(2)}$ \\
\hline & Olive and almond trees & $10^{(4)}$ & $27.5^{(5)}$ & $23.67^{(6)}$ \\
\hline & Old abandoned fields & $5.5^{(4)}$ & $80.7^{(7)}$ & $22.5^{(8)}$ \\
\hline & Recent abandoned fields & $1^{(4)}$ & $27.5^{(5)}$ & $30.8^{(9)}$ \\
\hline \multirow{8}{*}{$\begin{array}{l}\text { Natural } \\
\text { vegetation }\end{array}$} & Oak forest & $20^{(4)}$ & $80.7^{(7)}$ & $23.67^{(6)}$ \\
\hline & Dense Mediterranean forest & $5.5^{(10)}$ & $80.7^{(7)}$ & $22.5^{(8)}$ \\
\hline & Open Mediterranean forest & $2^{(4)}$ & $27.5^{(5)}$ & $22.5^{(8)}$ \\
\hline & Dense scrubland & $1^{(10)}$ & $80.7^{(7)}$ & $30.8^{(9)}$ \\
\hline & Disperse scrubland & $1^{(10)}$ & $27.5^{(5)}$ & $30.8^{(9)}$ \\
\hline & Poplar & $25^{(4)}$ & $98^{(11)}$ & $23.67^{(6)}$ \\
\hline & Bank vegetation & $3^{(4)}$ & $100^{(1)}$ & $8.33^{(2)}$ \\
\hline & Pine woodland & $10^{(12)}$ & $80.7^{(7)}$ & $24^{(12)}$ \\
\hline
\end{tabular}

664 PH: Plant height. CC: Canopy cover. RI: Rainfall interception. ${ }^{*}$ Average annual value. ${ }^{* *}$ Crop residues. ${ }^{(1)}$ Renard 665 et al. (1997); ${ }^{(2)}$ Ashby $(1999) ;{ }^{(3)}$ Eberbach and Pala $(2005) ;{ }^{(4)}$ IPE-GA $(2005) ;{ }^{(5)}$ Carreiras et al. $(2006) ;{ }^{(6)}$ Staelens 666 et al. (2006); ${ }^{(7)}$ Rodríguez-Calcerrada et al. (2007); ${ }^{(8)}$ Rodríguez and Schnabel (1998); ${ }^{9}$ Belmonte and Romero 667 (1998); ${ }^{(10)}$ Rambal et al. (2003); ${ }^{(11)}$ Nagler et al. (2004); ${ }^{(12)}$ Llorens and Domingo (2007).

670 TABLE 3. Comparison between estimated (RUSLE model) and measured $\left({ }^{137} \mathrm{Cs}\right)$ values of soil loss in several 671 control points $(\mathrm{n}=11)$ at barley fields in the Estaña catchment.

\begin{tabular}{lrrrr}
\hline Method & \multicolumn{4}{c}{$\mathrm{A}\left(\mathrm{Mg} \mathrm{ha}^{-1} \mathrm{yr}^{-1}\right)$} \\
\cline { 2 - 5 } & $\min$ & $\max$ & mean & $\mathrm{SD}$ \\
\hline RUSLE (K-texture) & 0.9 & 15.4 & 3.9 & 4.5 \\
RUSLE (K-K $\left.\mathrm{fs}_{\mathrm{fs}}\right)$ & 0.6 & 15.4 & 3.9 & 4.5 \\
RUSLE (K-K $\mathrm{fs}_{\mathrm{fs}}$-rocks) & 0.6 & 15.4 & 4.0 & 4.5 \\
${ }^{137} \mathrm{Cs}$ & 0.9 & 10.5 & 4.9 & 3.4 \\
\hline
\end{tabular}

672 
TABLE 4. Statistic values of annual soil loss for the different land-uses at the Estaña catchment.

\begin{tabular}{|c|c|c|c|c|c|c|c|c|c|c|c|}
\hline \multirow{2}{*}{\multicolumn{2}{|c|}{ Land-use and land-cover type }} & \multirow{3}{*}{$\begin{array}{c}\mathrm{K}\left(\mathrm{K}_{\mathrm{fs}} \text {-rocks }\right) \\
\left(\mathrm{Mg} \mathrm{h} \mathrm{MJ}^{-1} \mathrm{~mm}^{-1}\right) \\
\text { mean }\end{array}$} & \multirow{3}{*}{$\begin{array}{c}\text { LS } \\
(-) \\
\text { mean }\end{array}$} & \multirow{3}{*}{$\begin{array}{c}\mathrm{C} \\
(-) \\
\text { mean }\end{array}$} & \multirow{3}{*}{$\begin{array}{c}P \\
(-) \\
\text { mean }\end{array}$} & \multirow{2}{*}{\multicolumn{4}{|c|}{$\begin{array}{c}\mathrm{A} \\
\left(\mathrm{Mg} \mathrm{ha}^{-1} \mathrm{yr}^{-1}\right)\end{array}$}} & \multicolumn{2}{|c|}{ Total annual soil loss } \\
\hline & & & & & & & & & & \multirow[t]{2}{*}{$\left(\mathrm{Mg} \mathrm{yr}^{-1}\right)$} & \multirow[t]{2}{*}{ (\% of total) } \\
\hline & & & & & & $\min$ & $\max$ & mean & SD & & \\
\hline Anthropogenic & Paths & 0.0088 & 3.7 & 0.5027 & 1 & 0 & 306.3 & 18.7 & 34.4 & 23856 & 11.4 \\
\hline \multirow[t]{5}{*}{ Use } & Barley & 0.0107 & 3.3 & 0.1841 & 0.76 & 0 & 183.7 & 5.0 & 7.8 & 129772 & 61.9 \\
\hline & Pasture & 0.0097 & 3.7 & 0.0008 & 0.98 & 0 & 0.3 & $<0.1$ & $<0.1$ & 64 & $<0.1$ \\
\hline & Olive and almond trees & 0.0076 & 3.0 & 0.0422 & 1 & 0 & 9.5 & 1.1 & 1.6 & 476 & 0.2 \\
\hline & Old abandoned fields & 0.0095 & 6.6 & 0.0011 & 1 & 0 & 1.5 & 0.1 & 0.1 & 366 & 0.2 \\
\hline & Recent abandoned fields & 0.0104 & 4.6 & 0.0213 & 1 & 0 & 13.4 & 1.1 & 1.4 & 4177 & 2.0 \\
\hline \multirow{8}{*}{$\begin{array}{l}\text { Natural } \\
\text { vegetation }\end{array}$} & Oak forest & 0.0093 & 3.1 & 0.0013 & 1 & 0 & 0.4 & $<0.1$ & $<0.1$ & 139 & 0.1 \\
\hline & Dense Med. forest & 0.0106 & 6.0 & 0.0012 & 1 & 0 & 1.5 & 0.1 & 0.1 & 1603 & 0.8 \\
\hline & Open Med. forest & 0.0090 & 6.1 & 0.0320 & 1 & 0 & 48.6 & 2.1 & 3.1 & 34434 & 16.4 \\
\hline & Dense scrubland & 0.0098 & 6.0 & 0.0002 & 1 & 0 & 0.2 & $<0.1$ & $<0.1$ & 123 & 0.1 \\
\hline & Disperse scrubland & 0.0085 & 10.6 & 0.0170 & 1 & 0 & 13.7 & 1.5 & 1.4 & 7054 & 3.4 \\
\hline & Poplar & 0.0145 & 6.0 & 0.0005 & 1 & 0 & 0.2 & $<0.1$ & $<0.1$ & 7 & $<0.1$ \\
\hline & Bank vegetation & 0.0148 & 2.7 & 0.0170 & 1 & 0 & 7.2 & 0.6 & 0.8 & 1255 & 0.6 \\
\hline & Pine woodland & 0.0094 & 3.3 & 0.0006 & 1 & 0 & 0.1 & $<0.1$ & $<0.1$ & 5 & $<0.1$ \\
\hline
\end{tabular}


675 FIG. 1. Geographic situation of the study area in the province of Huesca (Spain). Average values of monthly 676 rainfall at the weather station of Canelles. Map of sampling points and land-uses of the Estaña catchment.
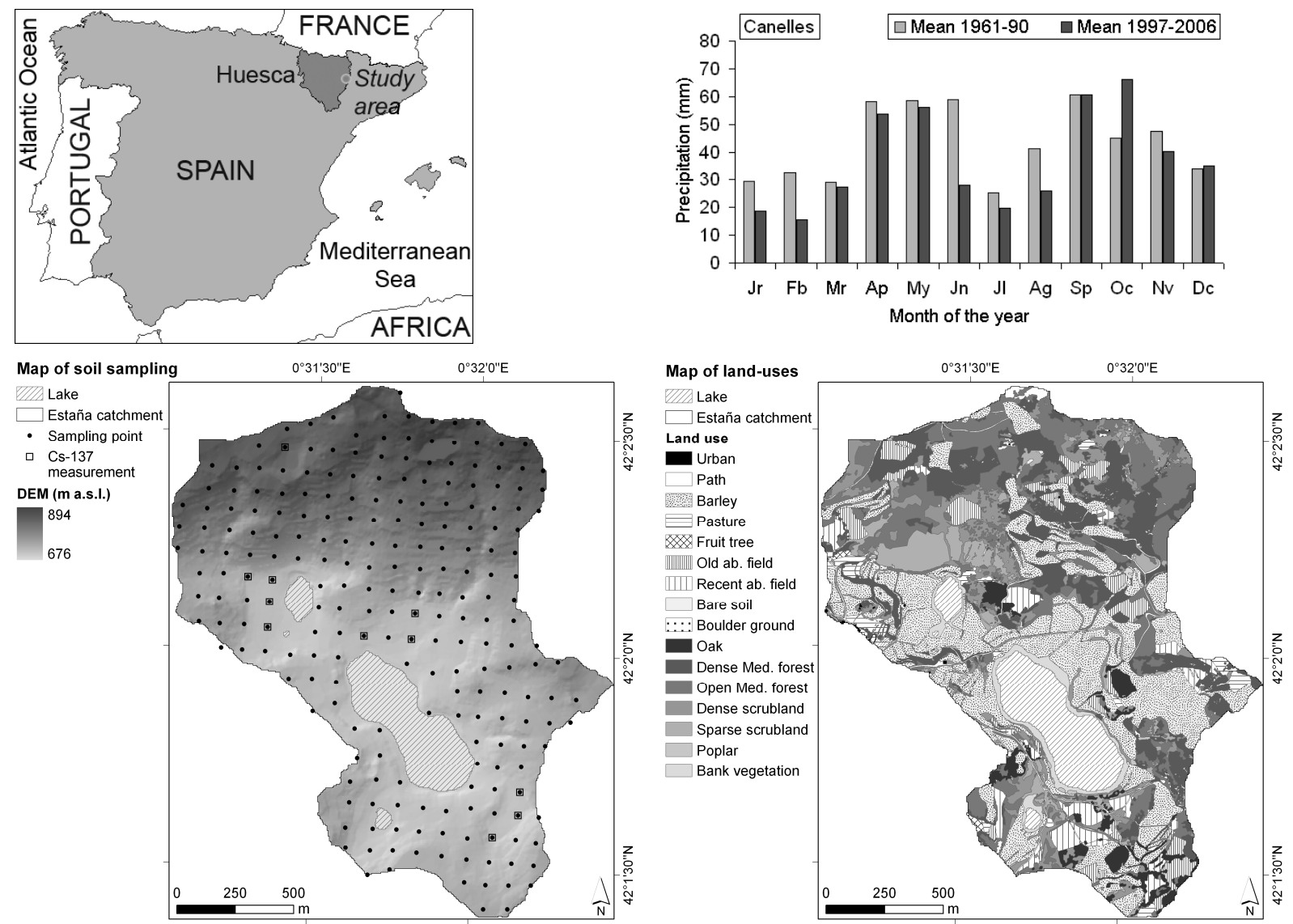
FIG. 2. Maps of the RUSLE factors of $K$-texture, $K$ - $K_{f s}, K-K_{f s}$-rocks, $L S, C$ and $P$ at the Estaña catchment.
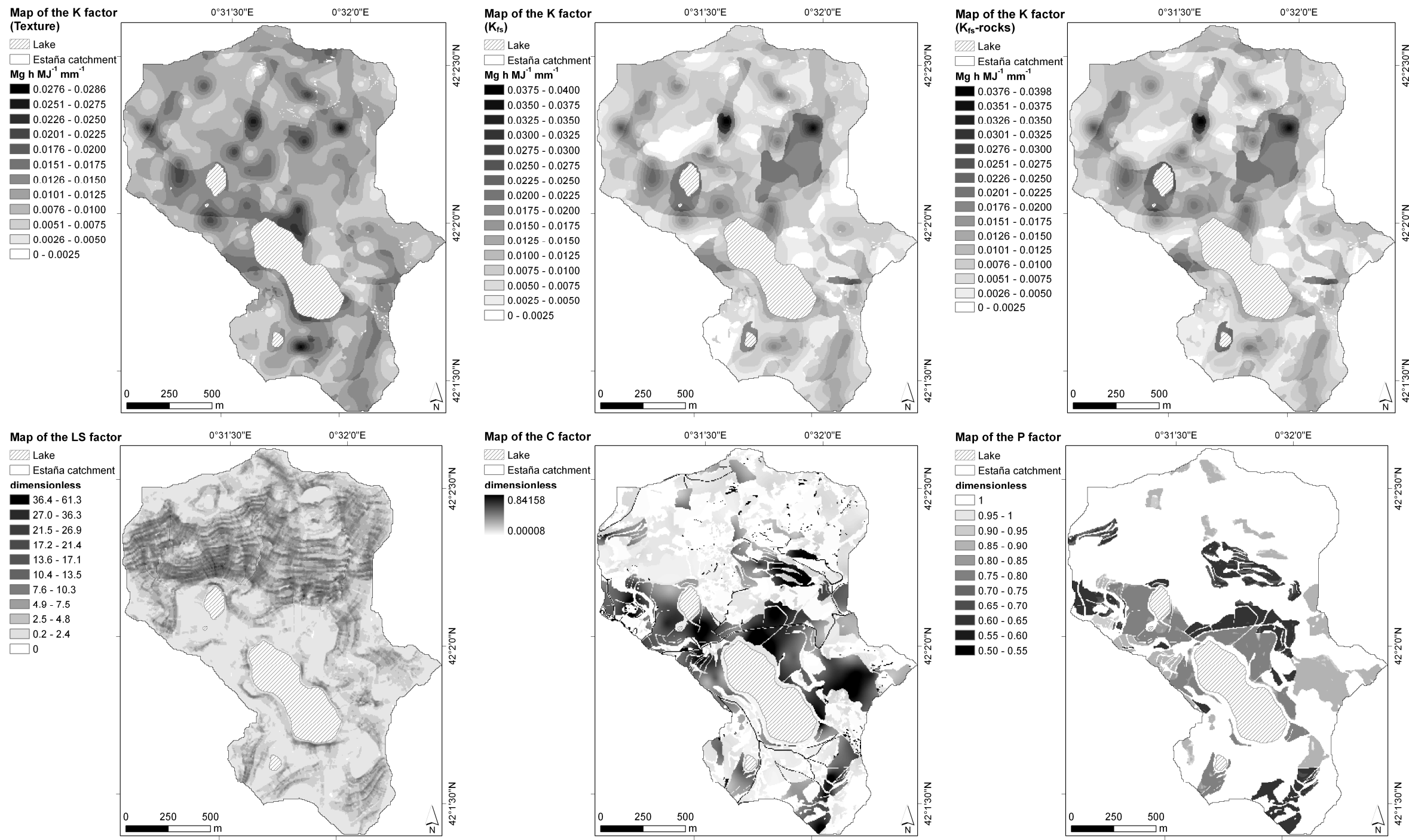

Map of the $\mathrm{C}$ factor

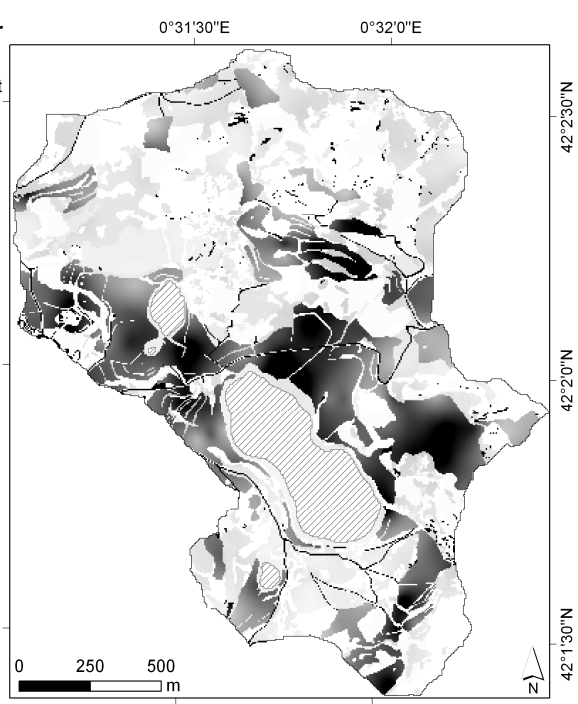

Map of the P factor
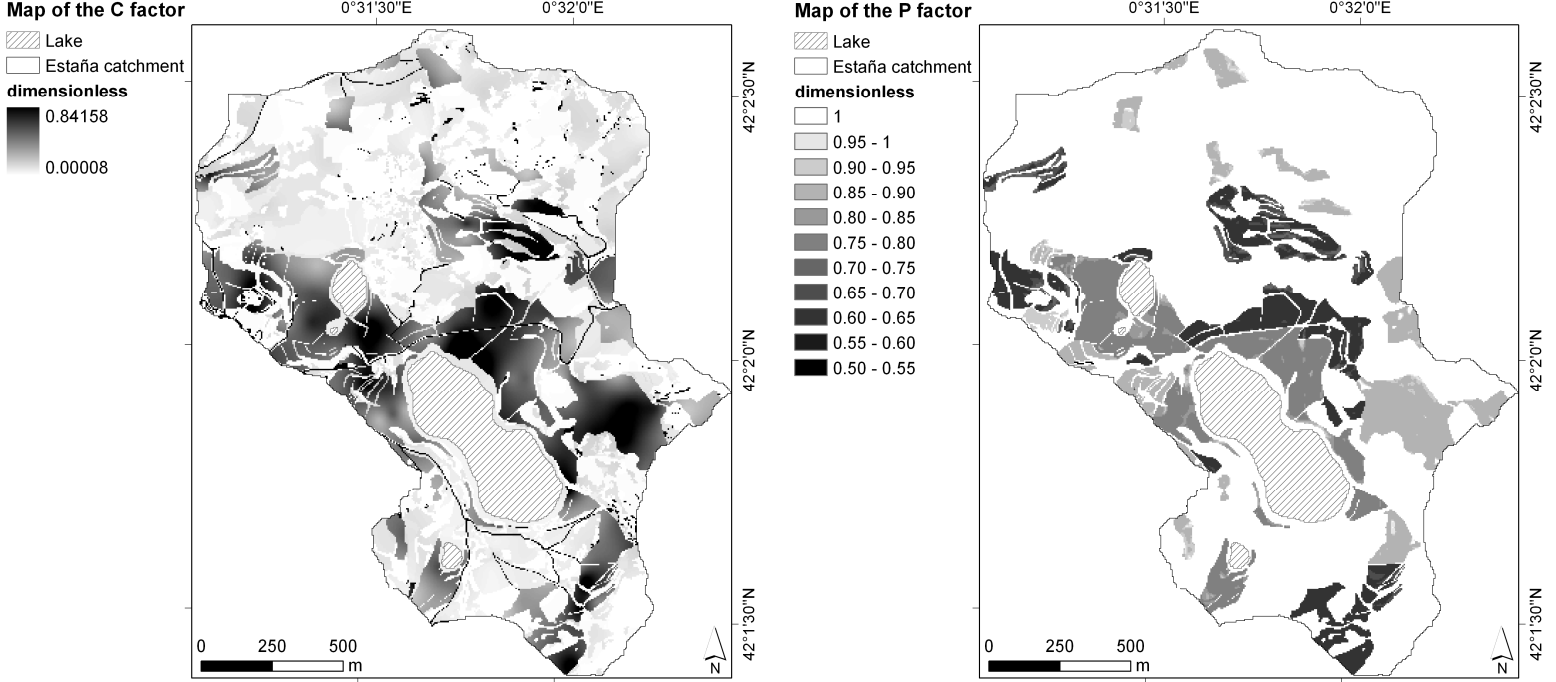
680 FIG. 3. Map and histogram of predicted soil erosion with the RUSLE model at the Estaña catchment.

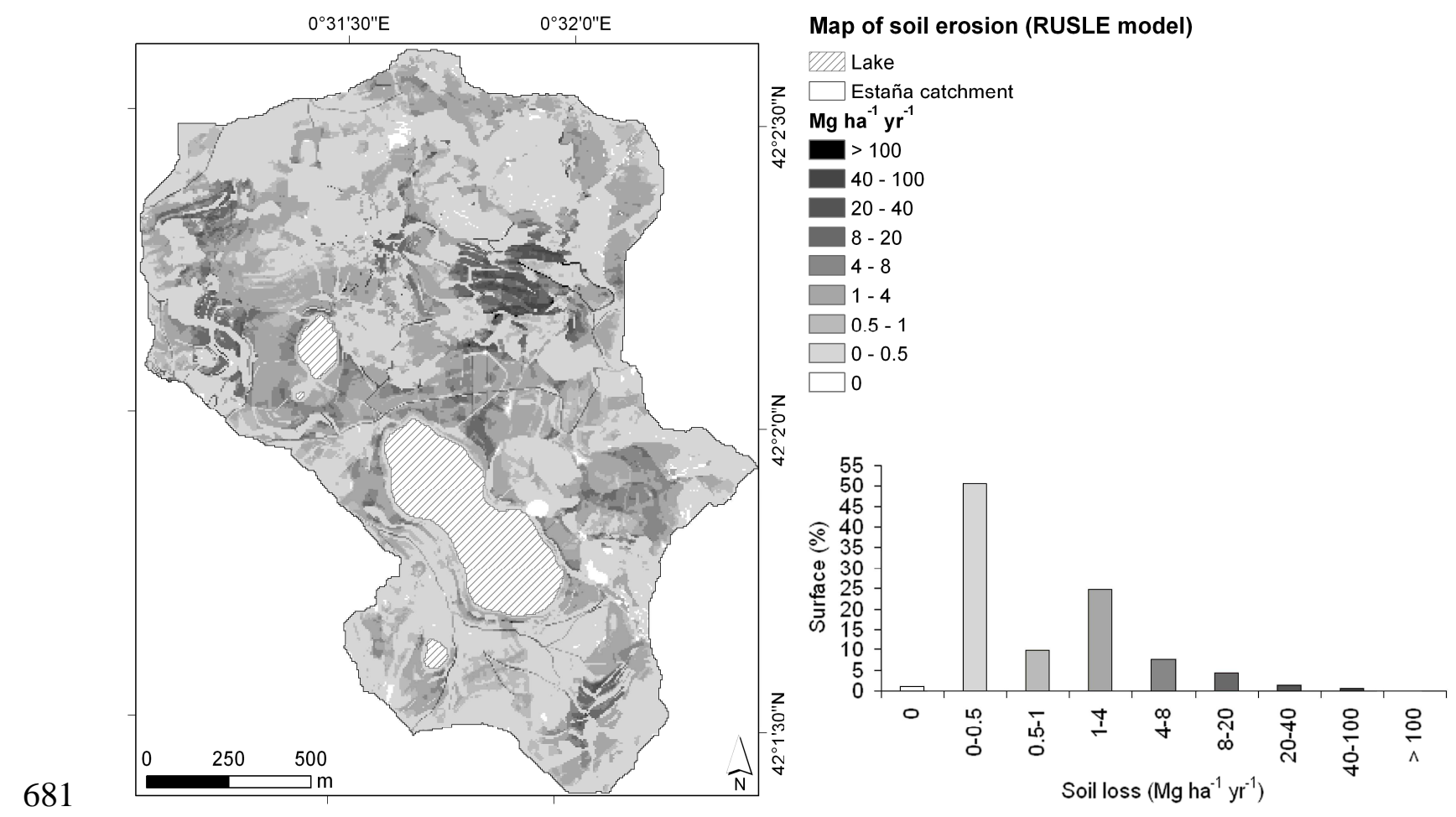


683 FIG. 4. Variation of the estimated values of soil loss at sampling points for barley fields, recently and old 684 abandoned fields, scrublands and oak and Mediterranean forest in relation with the three main types of lithology 685 and with different ranges of slope and orientation at the Estaña catchment.
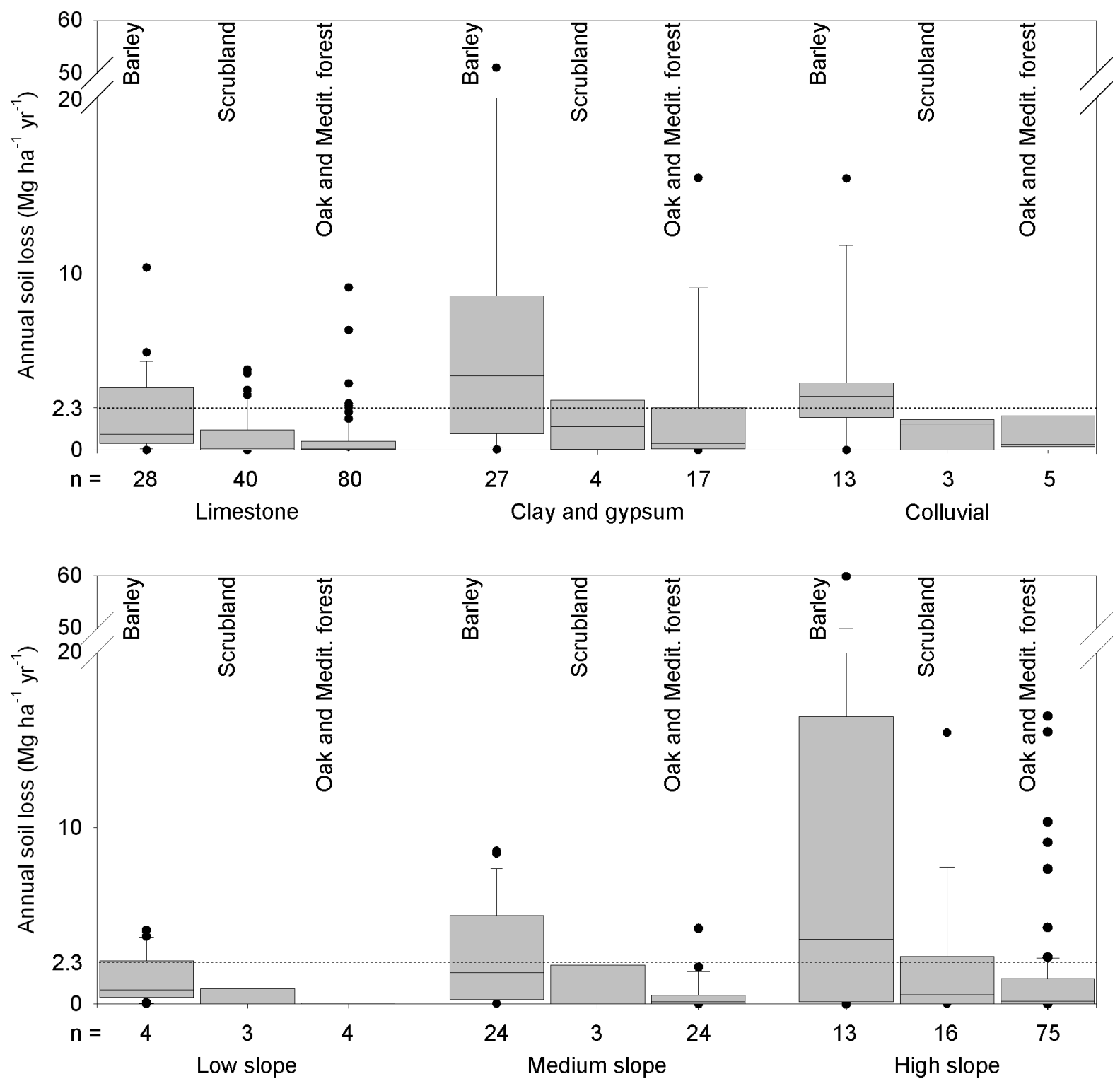

686 